\title{
Is Disease War? A Critical Analysis of the Covid-19 Discourse in Kenya
}

\author{
Albert Mogambi Moinani, Margaret Nasambu Barasa \\ Department of Languages and Lingusitics, Kisii University, Kenya \\ DOI: https://dx.doi.org/10.47772/IJRISS.2021.5327
}

\begin{abstract}
This paper critically analyzes the Covid-19 public address discourse by government officials in Kenya with a view to establishing the implications on public attitude and behavior towards fighting the pandemic. The paper utilizes the Critical Discourse Analysis (CDA) framework to examine the lexical choices the officials made and their implications for public attitudes and behavior towards the COVID-19 19 pandemic. The argument is that during times of crisis and uncertainty, the public looks up to those in authority for guidance and protection. The authorities also expect the public to comply and obey the government guidelines so as to manage the Covid 19 crisis. Public attitude and behavior therefore become an important component in crisis management, especially during periods of uncertainty occasioned by war and disease outbreaks. Studying language use by those in power is important because language is a powerful force that shapes people's mind and society's attitude and behavior. The study analyzed 90 utterances from key government officials regarding the Covid 19 prevention measures. The texts were extracted from the live briefings from the Audio-visual media in Kenya namely KBC TV, CITIZEN, KTN and NTV. The press briefings were between $3-00 \mathrm{pm}$ to 4:00pm on week days. The findings of the study reveal that the government officials perceived the pandemic as war whereas the public viewed it as a falsehood, hence non-existent. The findings of this study would be useful in shedding light on the role language plays in managing risks during times of crisis and uncertainty occasioned by pandemics such as the Covid-19 disease.
\end{abstract}

Keywords: Covid-19, attitude, behavior, discourse, containment measures

\section{INTRODUCTION}

$\mathrm{T}$ he words, phrases, idioms, and metaphors that those in authority use during their public addresses will inform and influence people's attitude and behavior. Public attitude and behavior are key components in managing crises and risks during times of uncertainty. The conceptualization of the magnitude of a disease largely depends on how it is described through language use. Consequently, the understanding that the Covid 19 as a disease or war is thus defined by the containment measures discourses from the key government officials. This paper sought to analyze the Covid 19 discourses from key government officials with a view to establishing their impact and effect on public attitude and behavior change in the fight against the pandemic.

During the Presidential address to announce the confirmation of the first COVID -19 case in Kenya, on $13^{\text {th }}$ March, 2020, the President declared that the country was officially going to war with an invisible enemy. The security agencies and other relevant authorities were put on a high alert. This diseases-aswar metaphor was repeated by other senior government officials in their areas of jurisdiction. The authorities warned the public against contravening the guidelines which the government outlined so as to contain the spread of the corona virus. The social implication of this diseases-as-war metaphor for the public attitude and behavior forms the thrust of this paper. Public attitude and behavior are vital elements in risk management in society during times of uncertainty. Government pronouncements during such periods play a big role in restoring public trust and confidence (Wong \& Jensen 2020).

The outbreak of the COVID-19 Pandemic ushered the country into a period of great uncertainty. Little was known about this disease and its treatment. This fact raised levels of anxiety and uncertainty among the public. The government came up with a number of guidelines aimed at containing the spread of the virus. Public compliance to these guidelines depended on trust and confidence in the government. The language of those in authority was important because it would either raise or lower public trust. That is why it is important for government to pay close attention to language use during times of crisis. Lack of trust and confidence during periods of uncertainty is a problem and also problematic both to the government and the public (Johnson \& Slovic, 1995, Lofstedt \& Bouder, 2017).

The SARS CoV2 (COVID-19), otherwise known as Corona virus was first reported in Wuhan city, China, in December, 2019 (World, Health Organization). This highly infectious disease spread to the rest of the world and by May 2020, it had claimed over three hundred thousand lives and infections close to six million people (www.who./int/information). The government informed the public that the COVID-19 disease was transmitted by touching contaminated surfaces. The virus could be picked by the hands and the once an individual touched the mucus membranes (nose, mouth and eye) it got into the body system causing severe respiratory problems which could lead to death. Infected persons could spread the virus when sneezing or coughing. The individual could send aerosol droplets into the air, hands or surface nearby from which somebody else could pick the virus. Individuals were therefore advised to wear masks, physical distance, sanitize hands regularly and wash hands thoroughly with soap and running water. 
The first COVID -19 case was reported in Kenya on March 13, 2020 (Ministry of Health, 2020). The government put the security, health and all relevant government agencies on high alert. The government then declared war against this invisible enemy (Daily Nation, Standard, March, 2020). Soon after, the government announced stringent measures so as to contain the spread of this disease. The measures included closing of all learning institutions indefinitely, nationwide dusk to dawn curfew, closing of all eateries, bars, open markets, churches and mosques. Suspension of all international passengers' flights, cessation of movements into and out of some cities and counties, masking, physical distancing, strict observance of hand-washing and sanitization, banning of public gatherings and immediate disposal of the dead (Ministry of Health, 2020).

Security agencies and other relevant authorities were instructed to enforce these measures. Security checks and roadblocks were mounted on all major highways in the county. Quarantine facilities were set up across the country and police were deployed throughout the country to enforce some of the measures. These measures were meant to stop the spread of the virus (Ministry of Health, 2020).

The authorities emphasized strict adherence to the containment measures as outlined by the government. The officials warned the public that stern action would be taken against those who failed to comply with these containment measures. Those caught would be taken into quarantine at their own cost and thereafter arraigned before court and jailed or fined (Ministry of Interior and coordination of national government, 2020).

The authorities' public addresses for the next couple of weeks indicated a steady rise in the number of infections with some deaths. The media also reported incidents of brutalities meted out on the public by the security agencies in the name of enforcing the containment measures. Stories of police shootings, manhandling, mistreatment in quarantine centers, arbitrary arrests, corruption and misappropriation of funds were reported by the media. Further still, stories and pictures of government supervised indecent disposal of COVID-19 victims circulated on the media (www.citizentv.co.ke).

The public responses indicated hatred and dissatisfaction. The public felt that they were being punished instead of being assisted to overcome the challenges brought about by the pandemic. They complained of lack of food, water, loss of incomes, lack of access to hospitals and other basics such as masks and sanitizers (www.citizentv.co.ke, www.ntv.co.ke). Frustration and desperation were decipherable from the public's responses. The public seemed to wonder aloud whether the government was at war with the citizens.

The question on whether diseases-is-war needs to be answered. How the authorities' language impacts on public attitude and behavior during times of crisis and uncertainty is worthy investigating. This is because public attitude and behavior are key components in risk management. Whether the COVID 19 pandemic is perceived as war or disease depends on the language used by the government authorities to sensitize the public on containment measures. Therefore, language becomes one of the key resources which can help authorities achieve public attitude and behavior change. This paper analyses the lexical choices used by the key government officials with a view to establishing whether the COVID 19 was viewed as a disease or war by the public. This perception in turn had a precedented impact on the containment measures.

\section{LITERATURE REVIEW}

Human society has always struggled against epidemics, though their outbreaks have varied widely in timing, location, speech, and scale (Gu and Lentian, 2020). Throughout history, various infectious diseases have raged in different parts of the world causing widespread damage besides shaping cultures and societies in different ways. The way governments handle the novel COVID-19 pandemic would have long-term impact on the socio-cultural and socio-economic fabric of societies in different parts of the world. The authorities' language use would play a crucial role in influencing and informing public behaviour and attitude are important component in risk management during periods of uncertainty (Loftedt and Bouder, 2017; Poortinga \& Nick, 2005). Such moments of uncertainty at times breed conflicts and disagreements between different players in society. Language plays a big role in resolving such conflicts for the common good of all (Barasa, 2014).

Language shapes the way human beings perceive the world around them. It is part of reality as well as shaper of reality (Halliday 1992, Fill \& Muhlhausler, 2001). The way society perceives COVID- 19 pandemic will to a large extend depend on the language use, more so by those in authority. Their language use would influence society's perception of the Covid-19 pandemic and its implications for humanity. Public perception will impact on public attitude and behaviour. Language is therefore an important tool which can help in risk management during the COVID-19 pandemic.

What is said or written by those in power affects public attitude. The language of those in authority can thus make a major difference to public opinion (Schultz, 1992, Chilton, 2014 Durant \& Lambrou 2009). The public will be influenced to accept, reject or even resist what those in authority espouse. Language should be used to bring about the public's understanding of the COVID-19 pandemic and inform about possible solutions or risk management measures. The leaders should therefore use language appropriately to enhance public undertaking of the COVID-19 pandemic with the view of managing the COVID-19 related crisis.

\section{DISCUSSION}

\section{A. Language use by government officials}

The lexical choices those in authority made are important in indicating how the government and consequently the public 
perceived and linguistically constructed the COVID-19 pandemic. The officials' perception informed the government policies and actions in mitigating COVID-19 uncertainties.

The following excerpts illustrate the officials' language use.

Excerpt 1:A group of people travelled to Homa Bay in a private vehicle pretending to be going for a funeral with an empty coffin. They were immediately put in quarantine. Today, I can confirm that the driver is positive. This person has taken the disease to Homa-Bay... Desire not to know someone who has been infected or has died from COVID-19 by the time you know it, it will be so chose to you and you may not even know... you may be the statistic... If we continue to behave normally, this disease will treat us abnormally!

The speaker's use of expressions such as desire not to know someone who is infected or has succumbed... you may be the statistic... this disease will treat us abnormally...instill fear and panic to the public. The fear that only war can bring and not a disease. The perceived enemy is the COVID 19 disease and the public are being warned not to associate themselves with the enemy lest they get destroyed or punished. Those who are infected or who behave in a manner that exposes them to risk are targets for profiling and punishment. These feelings are manifest in expressions such as the driver is positive... they were immediately put in quarantine indicates the stringent measures for those who don't follow the laid down guidelines. However, the mood of the statement presents the quarantine as a place for villains. Hence constructs the quarantine centres not as refugee camps or sanctuaries for prevention and treatment but as centres for punishment for those who do not observe the laid down guidelines. Under the background information and common knowledge on quarantine centres, the sick, the infected and the affected need love and kindness, however, the construction of the quarantine centres instead profiles the affected persons and also serves as a threat to those who are not ready to comply with the containment measures. Further, the statement, A group of people travelled to Homa Bay in a private vehicle pretending to be going for a funeral with an empty coffin, presents public defiance. The dishonesty behaviour of the fake mourners the officials mention indicates resistance and defiance of the government suggested crisis management measures.

Excerpt 2:COVID-19 is not a government disease... it is equally not the Governor's disease. You should bear in mind that we are fighting an invisible enemy. Let me tell you that you must take a COVID-19 test...you must, my friends whether you like it or not.

We have noted some youth in old town who are obstructing our officers from accessing suspected victims in the estate. We even saw some blocking an ambulance from picking a patient. We know them and we are going for them. We are coming for you. Who are you to fight the government?... tell them to run into the forest because we are coming for them. I don't actually need the police; I will pursue them personally. Don't joke, my friends!

The speaker's lexical choices indicate intimidation and threats. The official threatens the public with forced COVID19 testing, arrests and other punitive measures. The blocking of government officers from accessing parts of the city are indicators of resistance. Further, the action of the citizens blocking an ambulance indicates either ignorance of the masses about COVID-19 19 patients or just an act of resistance. These threats will most likely heighten the crisis. The public are perceived as non-entities who have no say in the management of the COVID-19 crisis. Expressions like... We are coming for you. Who are you to fight the government? tell them to run into the forest because we are coming for them construct a war picture rather than a disease one. Expressions such as... run to the forest...... who are you... portray the public as part of the enemy the government is out to fight. The statement sends a warning to the public and further informs them to be ready for a fight from the government. In addition, such expressions are demeaning and will most likely stir the public into resistance hence making it difficult for the government to deal with the situation effectively. I don't actually need the police; I will pursue them personally. Don't joke, my friends! The impact of these utterances further resulted in the public running away from their homes to avoid arrest or being taken to quarantine centres. This is because they perceived the utterance as a threat and in normal circumstance; one would not just sit and wait for the arrest. This is like war times where when one group feels powerless, the only solution is either to fight or flee.

Excerpt 3: And you chiefs, you must be on high alert. If any girl becomes pregnant in your area of jurisdiction, I will hold you personally culpable. You will be personally responsible for the girl's prenatal needs till she is delivered. It is only DNA which will exonerate you, if it turns out to be negative.... After all, where were you when the girl was being impregnated? Do I make myself clear!

The senior government officials threaten their juniors and blame them for crimes, mistakes and other illegal activities beyond their control. Blaming chiefs for teenage pregnancies and threatening them with punishment for crimes they may /may have not committed would not be fair unfair. It will lower their morale and trust in their seniors. The presupposition is that if local administrators such as chiefs are intimidated to such an extent, then who will oversee he implementation of the COVID 19 guidelines such as observation of the curfew and social distancing, gatherings during funerals, weddings etcetera? These accusations may stir feelings of hatred, hence adversely affecting the implementing of the COVID-19 containment measures. Further, threatening of junior government officials only makes the public perceive the COVID 19 pandemic as more of war than a disease. 
Except 4: Today, I want to confirm to you that we shall no longer import personal protective equipment (PPE). Our local manufacturers have started producing PPEs of very high quality. And I want to confirm that the PPEs we have been importing are substandard. It is by God's grace that our doctors have not died... Now; others have become so crafty and dishonest. Contact tracing has become the new headache. Those in quarantine provide wrong contact addresses making it very difficult to trace them when their test results are out. Some give us non-existent phone numbers. Surely, are we serious!

The speaker in excerpt 4 admits uncertainty. The use of substandard protective equipment by the health workers expose both the workers themselves and the general public, their families included to the virus. This admission of uncertainty will lower public trust in the government. Further, the statement... It is by God's grace that our doctors have not died... projects a feeling of fear which conditions the public mind in the perception of COVID-19 as a war. The assumption is that if a medic can die of COVID-19, what about a common citizen? Such imagination can instill fear in the people. In addition, the element of fear is evidenced in the reluctance of the citizens to provide correct contact information after testing for the virus. Those in quarantine provide wrong contact addresses making it very difficult to trace them when their test results are out. Some give us nonexistent phone numbers. Failure to trace contacts of those infected is equally an admission of uncertainty with similar effects. The giving of wrong information to the government indicates resistance due to lack of trust in the government

Excerpt 5: This is a unique war... the government is not overwhelmed.... This is a war against the disease and it is the people who are supposed to fight the disease, not the government... it is you and I. So, if there is, indeed if we are overwhelmed, it is we Kenyans who will be overwhelmed... the defense force is the individual himself or herself. If there is an issue of adherence and people don't adhere, the sufferer again is the individual himself or herself. At times it is true, it is a fact that Kenyans do not follow directives... let's be honest with ourselves, if you don't self-quarantine, it is your family you will be exposing and it is your families that you will kill. Let's not bury our heads in the ground like the proverbial ostrich. If people are going to die, they will be killed by us. Not any stranger... we started with 100, 200, we are now at 3,000. Oh yes, it is quite possible we are going even to triple.... Let me tell you something... this building here called Afya House.... has got its fair share of criminals. Like any other market place, there are few mad cases in here! It is just surprising that sometimes you find people... who are not supposed to be here for the last twelve years, still sitting here. This is the sort of place where you get people transferred and then you find they are sitting here. Why would you be transferred and you still want to be sitting in the same desk?

The speaker in excerpt 5 spreads responsibility to the citizens and further admits uncertainty. Afya House, the Ministry of
Health's headquarters coordinates and manages all the COVID-19 related crisis and risks management programmes. The senior official admits the presence of officials who cannot be trusted... this house has a fair share of criminals...there are hew mad cases... people who are not supposed to be here are still sitting here.... This admission of uncertainty will lower public trust and confidence in the authorities. The speaker admits failure to maintain high standards of professionalism at the Ministry of Health head office. The speaker further blames the public for the rise of infections and threatens the public with death... if people die, they will have been killed by ourselves not strangers...the defense force is the individual... the sufferer is the individual. The speaker implies that it is the public who should be blamed for the diseases hence spreading the responsibility and further trying to portray the government as unable to handle the situation. The public therefore becomes the physical manifestation of the invisible enemy the government is fighting. Regarding the public as the enemy will arouse feelings of hatred and resistance. The speaker exonerates the authorities and lays the blame on the public. The presence of officials in the ministry of health headquarters who defy government directives indicates the government failure to be accountable and responsible. This will most likely erode public trust in the government.

Excerpt 1-5 have illustrated the language used by the government officials in the fight against COVID-19 19 virus. The analysis of the language has revealed messages that instill fear and intimidation in the public which to some extent might derail the fight against the virus. The following Table 1 is a summary of the linguistic items used and their perlocutionary force (the effect the message has on the public).

TableI: Summary of Government Officials Language

\begin{tabular}{|c|c|}
\hline Language/Phrase/Expression & Perlocutionary force \\
\hline Invisible enemy & threat, uncertainty, war \\
\hline Frontline soldiers & Threat, war \\
\hline defense force is you yourself & Threat, uncertainty, war \\
\hline don't joke & Threat \\
\hline can't fight government & Threat \\
\hline must be tested & Threat, blame \\
\hline responsible for pregnancies & Threat, blame \\
\hline PPEs are substandard & Uncertainty \\
\hline by God's grace & Uncertainty \\
\hline take Corona to your parents & Blame, profiling \\
\hline it is your families you will kill & Blame,threat \\
\hline $\begin{array}{c}\text { Afya House has criminals }- \text { mad } \\
\text { people }\end{array}$ & Uncertainty \\
\hline $\begin{array}{c}\text { are not supposed to be here } \\
\text { you. will suffer first }\end{array}$ & Uncertainty \\
\hline disease will treat us abnormally & Threat, blame \\
\hline
\end{tabular}




\begin{tabular}{|c|c|}
\hline taken the disease to Homa Bay & Blame \\
\hline the driver is positive & Profiling \\
\hline $\begin{array}{c}\text { Desire not to know someone } \\
\text { infected }\end{array}$ & profiling, threat \\
\hline
\end{tabular}

\section{B. Language Use by the Public}

Critical analysis of the public's language use in their response to the government's implementation of the containment measures indicates dissatisfaction and suffering. The public largely feels oppressed, neglected and abandoned. The following excerpts illustrate this.

Except 6: We are a frustrated lot. We look like fools who do not understand anything. We truck drivers have made so much noise in vain. As if that is not enough, when we cross the border into Uganda, we face serious challenges. If one dares stop to answer to a call of nature, the people stone him and chase him away.

They claim that we are out to infect them with corona.

Nobody cares about drivers' wellbeing. Even after you volunteer yourself for testing, it takes up to two weeks to have your results...!

President Uhuru Kenyatta Muigai, we drivers are suffering. Mr. President, some of us are being sodomized and killed in Uganda!

The speakers' lexical choices indicate frustration and suffering. The public's appeal for government assistance seems to go unheeded. Claims of murder, sodomy and other forms of violence and discrimination indicate the extent of suffering. Despite persistent appeals for government aid, the authorities do not seem to take action. The drivers, for instance, seem to be perceived as public enemies because they are allegedly portrayed as carriers of the corona virus. They are mistreated and faced with hostility and yet they are the very people who transport essential commodities and foodstuffs to the people. Therefore, victimization of the truck drivers as essentially COVID-19 19 carriers instills fear in the drivers. Further, the delay in releasing the test results makes the fight against the disease very difficult.

Excerpt 7: President Uhuru, we urge you to open the markets. We are casual laborers who live from hand to mouth. We depend on the little we earn on daily basis for purchase of basic food stuffs.

The markets are closed, there are no jobs, and what do you want us to do? When we cross over to the posh estates, the rich chase us away, saying we may infect them with corona virus. Now, our families will starve to death. Dying of corona is better than starving to death. Every time we venture outside, police lobby tear gas at us... how insensitive can this government be!

Except 7 indicates resistance, defiance and profiling. The speaker claims that the government does not seem to care about the suffering of the poor. The police harass them; the rich who usually employ them for casual labour also chase them out of their premises. The speakers declare that they will defy government orders and risk contracting the virus instead of staying home then starve to death. Using the police to harass the public will lead to resistance and lower public trust. The mood of the message is that of resignation to fate but the majority who are poor vow to defy the government guidelines for survival.

Excerpt 8: The government has ordered us to stay home and keep washing and sanitizing our hands. The taps are dry... what do we wash our hands with? The government is not providing sanitizers... there is no water. There are no jobs. Markets are closed. We are supposed to pay house rent. Life is is very hard on us. The little money one chances upon... does one use it to buy soap or food? If the government provides us with food, we will stay home. But if they don't, then we will defy the orders. We can't dare sit and watch our children starve to death!

The speakers argue that the government has put in place strict measures without considering the people's well-being. Lack of water and food will make life difficult for the public. The speaker accuses the authorities of failure to provide the public with basic commodities. The public will hence defy the orders and risk arrest in order to look for food and other basic commodities. The speaker feels that they are being treated as criminals under punishments.

Excerpt 9: The trailers are parked here for far too long. The government does not want to test these drivers and set them free. All that the government keeps repeating to us is that the drivers are Covid-19 positive. What can we do so that these drivers are set free to continue with their journeys and leave Alone?

The speakers in excerpt 9 accuse the government of harboring hidden intentions. They seem to wonder why the officials do not expedite the testing process so as to reduce the risk of infecting the locals. This delay adds to the public's levels of uncertainty. This may lower public confidence in the government, hence resistance or defiance. The public feels that the government is deliberately keeping the drivers here longer to threaten and instill fear in the local residents.

Excerpt 10: There is no corona here...I have not seen anyone who is infected with this disease. I will never believe these stories by government officials until I see one who is infected. I have my mask but I only wear it to avoid being arrested. Otherwise it doesn't help us. I will only wear it when I see the police.

The speakers indicate their mistrust of the government...There is no corona here...I have not seen anyone who is infected with this disease. I will never believe these stories. Further, the masses are equally ignorant of the COVID-19 19 prevention measures...I have my mask but I only wear it to avoid being arrested. Otherwise it doesn't help 
us. I will only wear it when I see the police. They do not believe that the corona disease is real. Admitting that they only carry the masks to avoid arrest indicates resistance. This attitude may make it difficult for the government to achieve behavior change among the public.

Excerpt 11: They have opened churches and markets. Why do they close bars and schools? You can contract corona anywhere...markets, in matatus, in church. Let them give us a break. Those who will get infected will be infected, those who will die will die and those of us who will remain alive will go on with our Lives. The government should set us free to go on with our lives. We are fed up with these stories about corona. Where is the Covid-19 donor Funds... where are the masks and PPEs donated by...

This discourse takes place after the Government reviewed the COVID-19 19 containment measures and proposed the reopening of churches and markets. The speaker in excerpt 11 indicates doubt and mistrust. The argument is that even schools and bars should be reopened because corona is everywhere and anyone can catch it. The review of the guidelines seems to anger the masses and hence they adopt a defiance attitude... Let them give us a break. Those who will get infected will be infected, those who will die will die and those of us who will remain alive will go on with our Lives. The government should set us free to go on with our lives. In addition, the speakers seem to read mischief on the government's part.... Where is the Covid-19 donor Funds... where are the masks and PPEs donated by... the masses seem to question the distribution and use of the COVID-19 19 donor funds, the distribution of the masks and the PPEs. This feeling of mistrust will lead the public into ignoring the suggested containment measures, hence raising the risk of contracting the virus among the public. The doubting public may reject or ignore the government suggested containment measures, thus exposing themselves to more risk.

Table II: Summary of public's language

\begin{tabular}{|c|c|}
\hline Language/Phrase/Expression & Perlocutionary force \\
\hline We are suffering & Desperation \\
\hline We look like fools & Desperation, discrimination \\
\hline Nobody cares about drivers & Desperation, discrimination \\
\hline Drivers are COVID 19 positive & Profiling \\
\hline $\begin{array}{c}\text { Drivers are stoned and chased } \\
\text { away }\end{array}$ & Profiling, suffering \\
\hline $\begin{array}{c}\text { Dying of corona is better than } \\
\text { starving }\end{array}$ & Desperation \\
\hline What an insensitive government & Desperation, resistance \\
\hline Taps are dry & Desperation \\
\hline Hand to mouth & Desperation \\
\hline Casual laborers & Desperation \\
\hline Markets are closed & Desperation \\
\hline Food or soap & Desperation \\
\hline If they don't, we defy & Resistance \\
\hline We are sodomized and killed & Discrimination, desperation \\
\hline
\end{tabular}

The public language use indicates hatred. They feel that the containment measures are being used to punish them for circumstances beyond their control. The speakers' language use indicates that the authorities do not seem to mind the wellbeing of the public. They feel abandoned by the authorities and they suffer under the authorities who are supposed to protect them.

\section{FINDINGS}

\section{A. Finding 1}

The authorities perceived the COVID-19 pandemic as war. Speeches made by senior government officers were manifest with lexical items which indicated threats, blame and power to punish the public. The officials perceived the public as part of the enemy that was being fought. Consequently, the public's responses indicated dissatisfaction and hatred towards the government thus enhancing uncertainty.

\section{B. Finding 2}

Language is an important component in the management of risks during periods of uncertainty. The government should therefore make use of language experts in risk management. This would ensure efficiency and compliance in risk management. Successful containment of the Covid-19 pandemic would therefore require the right public attitude and behaviour.

\section{CONCLUSION}

Disease is not war. The government's perception of diseaseas-war would arouse feelings of hatred among the public. This is due to the seemingly punitive and insensitive implementation of the containment measures. This would lower public trust and confidence thus thwarting the government efforts in managing the COVID-19- 19 crisis. The use of security agencies who at times are accused of excessive use of force does not make maters any better. During times of crisis and uncertainty, the public needs words of love and kindness. Such language would indicate the authorities' empathy, hence winning public trust and support. Public trust and confidence are important components in risk management. The public would feel loved and cared for thus embracing and supporting the government in managing risks during such times of uncertainty.

\section{REFERENCES}

[1] Barasa, N.M. (2014) Discursive strategies in Kenya's 2008 post election consultation discourse. Unpublished Ph.D. thesis. Laikipia University.

[2] Chilton, P. (2004). Analyzing political discourse. London: sage

[3] COVID -19 government press briefing retrieved form https//www.youtube/watch.

[4] COVID-19 speeches by Ministry of Health briefing retrieved from

[5] COVID-19 Speeches retrieved from www.citizentv.co.ke

[6] COVID-19 Speeches retrieved fromwww.ntv.co.ke

[7] Durant, A \&Lambrou, M. (2009), Language and media. Oxford: Routledge,

[8] Gu,E \& Lantian, L. (2020) Crippled community governance and suppressed scientific/professional communities: a critical 
assessment of failed early warning for COVID-19 outbreak in China Journal of Chinese governance DOI: 10;10801 $23812346.2020(7) 40468$.

[9] Halliday, M. A. K (1992) ' New ways of meaning: challenge to applied linguistics': in Putz Martin (ed) 'Thirty years of linguistic evolution': Amsterdam: John Benjamin co.

a. https//www.health.go.ke

b. https//www.standardmedia.co.ke/covid-19

c. https//www.who.int/covid-19/information

[10] Johnson, B. \& Slovic, P. (1995). Presenting uncertainty in health risk assessment: Initial studies of its effects on risk perception and trust. Journal of Risk Research 15 (4)485-494).

[11] Lofstedt, R. \& Bouder, F. (2017). Evidence-based uncertainty analysis. What should we do now in Europe? A View Point. Journal of Risk Research 2017.131670
[12] Ministry of health website www//ministryhelath.org.ke

[13] Ministry of Interior and Coordination of National Government website: https://www.interior.go.ke

[14] Muehlhauser, P \& Fill, A. (2001). The Eco linguistics reader: language, ecology and environment. New York: continuum.

[15] Poortinga, W \& Nick, F.P (2003). Exploring the dimensionality of trust in risk Regulation Risk analysis23 (5): 961-972. DOI 10.11111 1539-6924.00373

[16] Schultz, B. (1992): Environmental matters and communicational challenges: in Australian journal of communication 21/3,26-39.

[17] Wong M. L .C \& Jensen, O. (2020). The paradox of trust perceived risk and public compliance during the COVID -19 pandemic in Singapore. Journal of risk researchDOI:10.1050/13669877.2020.1756386. 